Национална конференция с международно участие „ГЕОНАУКИ 2020“

National Conference with international participation "GEOSCIENCES 2020"

https://doi.org/10.52215/rev.bgs.2020.81.3.78

\title{
Geochemistry of bentonite clays from the Eastern Rhodopes (SE Bulgaria): preliminary results
}

\section{Геохимия на бентонитови глини от Източни Родопи (ЮИ България): предварителни резултати}

\author{
Rositsa Ivanova ${ }^{1}$, Dimitrina Dimitrova ${ }^{1}$, Ivanina Sergeeva ${ }^{1}$, Yana Tzvetanova ${ }^{2}$ \\ Росица Иванова ${ }^{1}$, Димитрина Димитрова ${ }^{1}$, Иванина Сергеева ${ }^{1}$, Яна Цветанова ${ }^{2}$ \\ ${ }^{1}$ Geological Institute, Bulgarian Academy of Sciences, Acad. G. Bonchev Str., bl. 24, 1113 Sofia, Bulgaria; \\ E-mails: rossiv@geology.bas.bg; didi@geology.bas.bg; sergeevai@geology.bas.bg \\ ${ }^{2}$ Institute of Mineralogy and Crystallography, Bulgarian Academy of Sciences, Acad. G. Bonchev Str., bl. 107, 1113 Sofia, \\ Bulgaria; E-mail: yana.tzvet@gmail.com
}

Keywords: major and trace elements, bentonite clays, Eastern Rhodopes.

\section{Introduction}

Voluminous explosive volcanism took place in the Eastern Rhodopes (SE Bulgaria) during Paleogene and large amounts of tephra were accumulated. Both acid and intermediate in composition glassrich pyroclastic rocks were widely affected by processes of zeolitization and argillization resulting in formation of large zeolite (Djourova, Aleksiev, 1984; Raynov et al., 1997; Yanev et al., 2006, etc.) and bentonite deposits (Atanassov, Goranov, 1988). Bentonite clays originated by transformation of both acid and intermediate glasses as several deposits and many occurrences have been identified (Atanassov, Goranov, 1962; Atanassov et al., 1964, Atanassov et al., 1972, etc.). Bentonite clays associated with acid tuffs (known as first Oligocene acid phase) like Zlatna Livada and Enchets deposits, we refer here as A-bentonites. Bentonite clays developed on the expense of intermediate volcanic glass like Propast-Dobrovolets deposit hosted by the second intermediate volcanic phase, are referred as I-bentonites, respectively. Due to their wide application in the industry bentonite clays in Bulgaria have been an object of intensive studies since $60 \mathrm{~s}$ of the last century but there are no published data on their trace and rare-earth elements contents. In this work we report data from LA-ICP-MS analyses of 7 bentonite samples from the Eastern Rhodopes as three of the samples come from two bentonite deposits - Zlatna Livada and Propast-Dobrovolets.

\section{Material and methods}

The two analysed samples (A-ZL and A-Ba) from A-bentonites have been collected in a small quarry located to the north-east of Zlatna Livada village (Chirpan district) and to the south of the town of Kardzhali, near Balabanovo village. The I-bentonites have been sampled to the east and south of the town of Kardzhali. Two samples (I-PD ${ }_{\mathrm{t}}$ and I-PD $\mathrm{D}_{\mathrm{b}}$ ), collected near Sedlovina village and just to the south of Kardzhali suburbs, represent respectively the topmost and lowermost parts of the interval hosting Propast-Dobrovolets deposit. The three additional samples (I-Gr, I-Gl and I-Sv) were collected further south near the villages of Gruevo, Gluhar and Svoboda. Whole-rock samples have been analysed for major oxides using XRF spectroscopy in Bureau Veritas Mineral Laboratories (Canada). Trace elements have been measured in the Geological Institute, Bulgarian Academy of Sciences. The LA-ICPMS system used consists of a $193 \mathrm{~nm}$ ArF excimer laser (ATLEX-SI, Germany) linked with an ELAN DRC-e ICP-MS instrument (Perkin Elmer, Canada). The analyses were performed with $100 \mu \mathrm{m}$ ablation pits on fused pellets with lithium tetraborate at $1050^{\circ} \mathrm{C}$. External standardization on NIST glass standard SRM-610 allows linear drift correction of the spectrometer and provides relative element concentrations. These element concentrations were transformed into true values by internal standardization (a known concentration of Si, determined by XRF) using "Sills" program (Guillong et al., 2008) for data reduction. The XRD measurements have been carried out in the Geological Institute, Bulgarian Academy of Sciences using HUBER Image Plate Guinier Camera G670 (40 kV and 40mA, step size of $0.0052 \theta$ with Ge monochromator on primary beam providing pure $\mathrm{Cu} \mathrm{K} \alpha$, radiation; diffraction data were collected in the range of $4-100^{\circ} 2 \theta$, 
simultaneously) and Institute of Mineralogy and Crystallography, Bulgarian Academy of Sciences, using D2 Phaser - Bruker AXS Bragg-Brentano diffractometer operated at $30 \mathrm{kV}$ and $10 \mathrm{~mA}$ with a step size of $0.052 \theta$ and a counting time of $1 \mathrm{~s} / \mathrm{step}$.

\section{Results}

The analyzed samples display differences in major-element abundances between bentonites developed on acid and intermediate volcanic precursor as well as noticeable variation within the group of I-bentonites. Except being richer in $\mathrm{SiO}_{2}$ (up to $73.73 \%$ ), A-bentonites are depleted in $\mathrm{TiO}_{2}(0.08-0.19 \%), \mathrm{Fe}_{2} \mathrm{O}_{3}(0.78-1.65 \%), \mathrm{MgO}$ (1.69-1.81\%) and $\mathrm{P}_{2} \mathrm{O}_{5}(0.14 \%)$. I-bentonites show variable contents of $\mathrm{Fe}_{2} \mathrm{O}_{3}(5.76-9.54 \%)$, $\mathrm{MgO}(2.89-5.18 \%), \mathrm{K}_{2} \mathrm{O}(1.72-5.19 \%)$ and $\mathrm{Na}_{2} \mathrm{O}$ (0.13-3.03\%). Two samples (A-Ba and I-Gr) have high LOI values $(16.1 \%$ and $14.7 \%)$, and display lower $\mathrm{SiO}_{2}$ contents $-50.49 \%$ and $50.38 \%$, respectively. These two samples are enriched in $\mathrm{CaO}$, especially $\mathrm{A}-\mathrm{Ba}-17.5 \%$. The variations in major-elements abundances are due to differences in precursor glass composition, some diversity of primary and authigenic mineral assemblages (Table 1) as well as possible variation in composition of the major rock-forming phase - montmorillonite (Atanassov, Goranov, 1988; Yanev et al., 2004; Ilieva, 2007). For example, samples rich in $\mathrm{CaO}$ contain calcite; zeolites fix some more sodium in sample I-Sv $\left(\mathrm{Na}_{2} \mathrm{O}-3.03 \%\right)$.

Trace elements distribution patterns of the studied samples have downward-sloping primitive mantle-normalized profiles with LILE enrichment, negative Ti anomaly and positive U-Th and $\mathrm{Pb}$ anomalies (Fig. 1a). The negative Ba anomaly is not well expressed in all samples and is even missing in sample I-Gl. Chondrite-normalized profiles are LEEE enriched compared to HREE, with negative Eu anomaly (Fig. 1b), which is stronger in A-ZL. The contents of the compatible in the magma processes elements $\left(\mathrm{Ni}, \mathrm{Cr}, \mathrm{Co}, \mathrm{Sc}, \mathrm{Eu}^{2+}\right)$ are low and relatively uniform. The highest contents of $\mathrm{Ni}$ and $\mathrm{Cr}$ are registered in A-bentonites, $18.5 \mathrm{ppm}$ (in A-Ba) and $86.4 \mathrm{ppm}$ (in A-ZL), respectively. The I-bentonites are slightly enriched in Co (11.6-17 ppm), Sc (12.8-18.9 ppm) and $\mathrm{Eu}$ $(1.15-1.38 \mathrm{ppm})$. The other transitional elements as $\mathrm{Cu}$ and $\mathrm{V}$ are also enriched in I-bentonites. Some of the incompatible elements ( $\mathrm{Ba}, \mathrm{Sr})$ behave as compatible in respect to some primary magmatic minerals (Bt, Fsp) present in the studied samples. The contents of $\mathrm{Ba}$ are higher in the samples enriched in crystal clasts, and especially, of lava lithics (I-Sv - 1335 ppm, I-Gl - 3405 ppm), while $\mathrm{Sr}$ is more abundant in A-bentonites (758-837 ppm). Rubidium and Cs are highly incompatible during magma crystallization and the results obtained indicated they remain incompatible during the bentonitization of the volcanic glass: the contents registered are low and relatively uniform ( $\mathrm{Rb} 78-150 \mathrm{ppm}$; Cs 3-27 ppm). It seems they prefer other secondary minerals (as adularia and clinoptilolite) present in small amounts in some of the studied samples (Table 1). Accordingly, some minor enrichment of $\mathrm{Rb}(290 \mathrm{ppm})$ is registered in sample $\mathrm{I}_{-} \mathrm{PD}_{\mathrm{b}}$ that contains some adularia (Yanev et al., 2004). However, the highest value of Cs (27 ppm) was not measured in the richest in zeolites sample. The behavior of HFS elements in magmas is controlled by accessories and, respectively, the I-bentonites are relatively enriched in $\mathrm{Zr}$ (187-318 ppm), Hf (5-7.6 ppm), and REE (LREE 150-199 ppm). The other HFS element (U, Th, Nb, Ta) are present in detectable amounts in all samples but their variation seems mostly random (U 4.5-12.7 ppm; Th 19-36 ppm; Nb 10-26 ppm; Ta 0.8-2.3 ppm). The only exception is A-NZ sample, showing highest contents of both $\mathrm{Nb}$ and Ta. The highest $\Sigma$ REE value (199 ppm) is obtained for I-Gl and it is probably due to amphibole presence.

Table 1. Mineral assemblages in the studied samples based on XRD data of bulk samples and microscopic observations of thin sections

\begin{tabular}{|c|c|c|c|c|c|c|c|c|c|c|c|c|c|c|}
\hline Sample & $\mathrm{Pl}$ & Kfs & $\mathrm{Bt}$ & Qz & Amp & Lithics & Mnt & $\mathrm{Cpt}$ & Anl & $\mathrm{Cal}$ & $\mathrm{O}-\mathrm{CT}$ & Php? & Ilt & Adl \\
\hline A-Ba & + & + & & + & + & + & + & + & & + & + & & + & \\
\hline A-ZL & + & & & + & & & + & + & & & + & & & \\
\hline $\mathrm{I}-\mathrm{PD}_{\mathrm{b}}$ & + & & & + & & & + & + & & + & & & + & + \\
\hline $\mathrm{I}-\mathrm{PD}_{\mathrm{t}}$ & + & + & & & & & + & + & & + & & & & \\
\hline $\mathrm{I}-\mathrm{Gr}$ & + & + & + & & & & + & & + & & & & & \\
\hline $\mathrm{I}-\mathrm{Sv}$ & + & + & & & & + & + & + & + & & + & & & \\
\hline I-Gl & + & + & & + & + & + & + & & + & + & & + & & \\
\hline
\end{tabular}

Notes: the primary magmatic components are shaded; O-CT, Opl $\pm \mathrm{Crs} \pm \mathrm{Trd}$; the mineral name abbreviations are after Whitney, Evans (2010) 

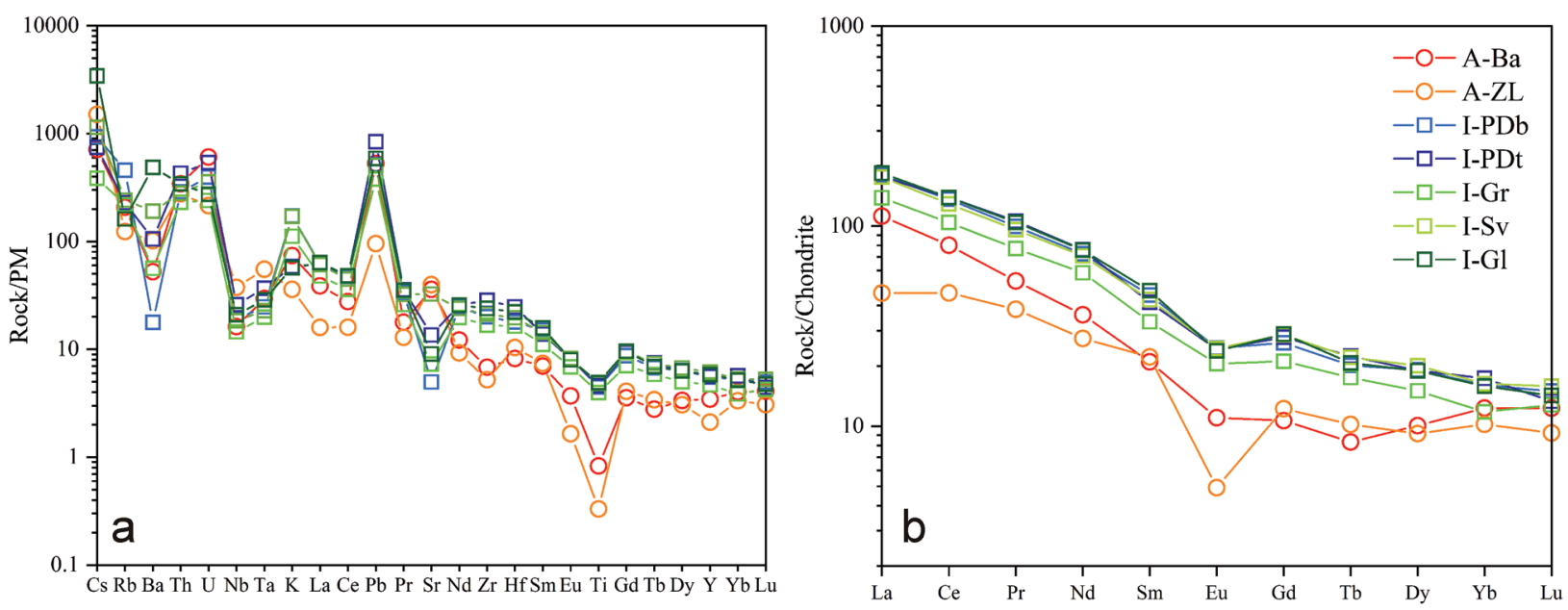

Fig. 1. $a$, primitive mantle-normalized trace-element spider diagram; $b$, chondrite-normalized REE diagram of bentonite clays from the Eastern Rhodopes. The normalization values are from Sun and McDonough (1989).

\section{Conclusions}

The obtained results show no significant accumulation of trace elements in the studied samples. Their overall chemical composition is strongly influenced by the volcanic glass chemistry, the presence and abundance of magmatic minerals and lithic clasts and to lesser extent by secondary authigenic mineral associations. Respectively, their trace element signature is similar to that of the unaltered extension-related orogenic volcanic rocks in the Eastern Rhodopes. No correlation between any of the trace elements measured and the relative montmorillonite abundance (in samples A-ZL and I-PD) have been established. Nevertheless, these data complete the knowledge of bentonite clays from the Eastern Rhodopes; they can shed more light on the connection between volcanic precursors and alteration products and can provide deeper insight into the process of glass transformation.

Acknowledgements: This study was funded by the Bulgarian National Science Fund grant KP-06OPR04/3.

\section{References}

Atanassov, G., A. Goranov. 1962. Bentonitic clays from the region of the town of Kardzhali. - Ann. Univ. Sofia, 56, 2-géol., 149-188 (in Bulgarian with English abstract).

Atanassov, G., A. Goranov. 1988. Bentonite clays. - In: Trashliev, S. (Ed.), Non-metallic Mineral Deposits. 1 - Exogenic Industrial Minerals and Rocks. Sofia, Tehnika Publ. House, 102-120 (in Bulgarian with English abstract).

Atanassov, G., A. Goranov, D. Stefanov, S. Trashliev. 1964. Bentonitic clays from Zlatna Livada village, Chirpan area. - Ann. Univ. Sofia, 58, 1-géol., 145-156 (in Bulgarian with English abstract).

Atanassov, G., A. Goranov, D. Stefanov. 1972. Bentonitic clays from the region to the south of Kardzhali and to the west of
River Varbitsa. - Ann. Univ. Sofia, 64, 1-géol., 203-224 (in Bulgarian with English abstract).

Djourova, E., B. Aleksiev. 1984. Zeolitic rocks deposits of economic value in North-Eastern Rhodopes. - Ann. Univ. de Sofia, 78, 1-géol., 256-262 (in Bulgarian with English abstract).

Guillong, M., D. L. Meier, M. M. Allan, C. A. Heinrich, B. W. D. Yardley. 2008. Appendix A6: SILLS: A MATLABbased program for the reduction of laser ablation ICP-MS data of homogeneous materials and inclusions. - In: Sylvester, P. (Ed.), Laser Ablation ICP-MS in the Earth Sciences. Current Practices and Outstanding Issues. Mineral. Assoc. of Canada Short Course 40, Vancouver, 328-333.

Ilieva, A. V. 2007. Crystallochemical and Structural Features of Natural and Modified Montmorillonites from Bulgarian Deposits of Bentonite Clays. Unpublished PhD Thesis. Sofia, Institute of Mineralogy and Crystallography, Bulgarian Academy of Sciences, $127 \mathrm{p}$.

Raynov, N., N. Popov, Y. Yanev, P. Petrova, T. Popova, V. Hristova, R. Atanasova, R. Zankarska. 1997. Geological, mineralogical and technological characteristics of zeolitized (clinoptilolitized) tuffs deposits in the Eastern Rhodopes, Bulgaria. - In: Kirov, G., L. Filizova, L., O. Petrov (Eds.), Natural Zeolites, Sofia'95, Pensoft, Sofia-Moscow, 263-275.

Sun, S.-S., W. F. McDonough. 1989. Chemical and isotopic systematics of oceanic basalts: implications for mantle composition and processes. - In: Saunders, A. D., M. J. Norry (Eds.), Magmatism in the Oceanic Basins. Geological Society, Special Publication, 42, 313-345.

Whithey, D., B. Evans. 2010. Abbreviations for names of rockforming minerals. - Am. Mineral., 95, 185-187.

Yanev, Y., J.-J. Cocheme, R. Ivanova, O. Grauby, E. Burlet, R. Pravchanska. 2006. Zeolites and zeolitization of acid pyroclastic rocks from paroxysmal Paleogene volcanism, Eastern Rhodopes, Bulgaria. - N. Jb. Miner. Abh., 182, 3, 265-283.

Yanev, Y., R. Ivanova, Tz. Iliev, S. Gier. 2004. Part I - Eastern Rhodopes. - In: Yanev, Y., M. Fytikas (Eds.), Paleogene and Recent Volcanism in the Eastern Rhodopes (Bulgaria) and on Milos Island (Greece), and Related Industrial Minerals. Guidebook for Post-Congress Excursion P 36. 32nd International Geological Congress, Florence, Italy, August 20-28, 7-13. 